\title{
PLASTIC WASTE MANAGEMENT, A CONCERN FOR COMMUNITY
}

\author{
Piyush Gupta* \\ * SRM Institute of Science and Technology, Department of Chemistry, NCR Campus, Modinagar, \\ Ghaziabad, Uttar Pradesh, India
}

corresponding author: Piyush Gupta, e-mail: piyushg.1977@gmail.com

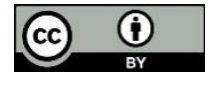

This work is licensed under a

Creative Commons Attribution 4.0

$\underline{\text { International License }}$
Review paper

Received: April $3^{\text {rd }}, 2020$

Accepted: May $8^{\text {th }}, 2020$

HAE-1944

https://doi.org/10.33765/thate.11.2.3

\begin{abstract}
Plastics i.e. polymers are long chains or networks of monomer molecules which can be fabricated in desired shape, colour and specifications. The multi-functionality of this macromolecule has made it an integral part of society. Due to being given immense importance in various industrial sectors, like information technology, electrical, as well as electronics industries, intelligent, smart and advanced packaging systems, agriculture, automobiles, biomedical applications, etc., they are quite indispensable for the modern generation. The huge demand and high frequency usage have alarmed a number of countries littered with plastic wastes which need to be attended immediately. The effects of plastic solid waste on environmental living and non-living components are noticeable in the ever-increasing level of plastic pollution both on land and in the oceans globally. This paper compiles the various aspects and prospects of disposal methods like landfilling, recycling, progress in recovery and management of plastic waste (i.e. primary, secondary, tertiary and quaternary) in order to minimize its huge volumes. The depolymerisation process is the key technology behind its success which provides a high yield of product and a minimal amount of waste. Few innovative methods other than recycling published by different researchers are also discussed in this paper.
\end{abstract}

Keywords: plastic solid waste (PSW), non-biodegradable, pollution, health hazards, recycling

\section{INTRODUCTION}

Mankind is struggling with too many problems related to environment, like pollution, crisis of demand and supply of energy, soil quality, food security, waste management, population explosion, loss of biodiversity etc. Nowadays, the waste is composed of an endless list of dangerous materials, such as medical waste, paints, fluorescent tubes, fertilizers and pesticides containers, plastic packaging, batteries and discarded digital devices, electronic and electrical appliances. Municipal solid waste (MSW) mainly comprises kitchen, pantry, and yard wastes, paper and plastics discarded by households, industries, institutions and commercial structures. The flexible, non-recyclable, easy to mould plastic materials are being used by each generation in a wide range of applications, like 3D printing, 
packaging, construction etc. The quantum of post-consumer plastic waste is regularly increasing due to rapid rise in population, developmental activities and changes in lifestyle. It generally ends up in unplanned dumpsites in developing countries and persists in environment for a long period of time. The wind can easily carry lightweight plastic bags. This results in clogging drain pipes, flooding, preventing rainwater from penetrating the soil and loss of crops. Live stocks or marine life often mistake plastic bags for food which is the dark side of this versatile material. Thus, plastic waste materials are causing severe harmful effects on the environmental dimensions and our society as well. The scientists from the Marine and Environmental Sciences Centre have reported plastic pollution commonly referred to as "plasticrusts" in marine ecosystems (Madeira, a volcanic Portuguese island of northwest Africa). They observed the deposition of grey and blue patches of melted plastics encrusted on the rocks of the oceans which may cause damaging impacts on flora and fauna of the aquatic ecosystem. The potential effects of "plasticrusts" found in the intertidal rocky shores of a volcanic Atlantic island are still unknown, but it has the potential to affect the

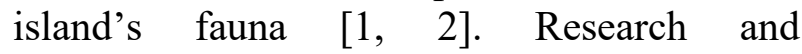
development studies are now focused on exploring whether ingestion of plastic rubble by aquatic organisms renders lethal exposures for individuals who depend on seafood with specific relevance to lead, cadmium, methyl mercury, plasticizers, phthalates, stabilizers, Bisphenol A, etc. The consumption of plastic waste by intertidal animals might be a new course for entering plastics into trophic levels of interlinked food webs. Advanced new disposal methods, such as recycling, pulverization, pyrolysis, gasification, incineration, sanitary and secured landfills, etc. are used to resolve the plastic waste problem. Transformation of waste into energy such as biogas, biofuels and novozymes (enzymebased solutions which convert low-grade oils and cooking oils into biodiesel) is a smart move. Uncontrolled, unplanned dumping and burning waste is not considered as an adequate practice from environment and health perspective.

\section{PLASTIC: A BOON OR BANE}

Plastics are the chains of combined carbon atoms, comprising oxygen, nitrogen or sulphur. These are prepared from organic materials found in nature, such as crude oil, coal, cellulose, minerals and natural gas. Crude oil or raw petroleum is a non-renewable fossil fuel which is a complex combination of hydrocarbons and several compounds that needs refining before its usage. The major elementary chemical components of petroleum are hydrogen $(\mathrm{H})$, oxygen $(\mathrm{O})$ and carbon $(\mathrm{C})$. The production of plastics, gasoline, kerosene, diesel and several forms of petrochemicals starts with the distillation or thermal decomposition of crude oil in an oil refinery. This process divides crude oil into a number of fractional constituents. Every single fraction comprises of hydrocarbons (organic compounds comprises of carbon (C) and hydrogen $(\mathrm{H})$ ), which differs in chain length and structural properties. Naphtha, a fractional component is the essential compound for the manufacture of plastics. Naphtha is decomposed thermally and divided into different components, like ethylene and propylene by using differences in their boiling points (temperature at which naphtha oil changes from liquid to gaseous phase), which are the necessary raw ingredients for plastics. The two main processes i.e. polymerisation and polycondensation are used to produce plastic polymers in presence of a suitable catalyst. It is mandatory to make lowmolecular weight compound (monomer) first and then bind them together to yield a highmolecular weight compound (polymer). This chemical addition of monomers to get polymers is known as polymerisation. The word "mono" means "one or single", while "poly" means "many" and "mer" means "parts". The polymerisation requires heat, pressure, light and appropriate catalysts (reaction initiators) and thus ethylene and 
propylene monomers are polymerized into polyethylene and polypropylene respectively.

The term "plastic" used first in 1925 came from Greek word "plastikos", which means moulded or capable of being shaped. Plastics are the polymeric materials that contain some chemicals as additives to improve performance, enhance plasticity and durability or reduce costs. All types of plastic are polymers, but all the polymers are not essentially plastic. Plastic is one of the best innovations of the millennium because it is lightweight, non-breakable, resistant to corrosion and decay, easily transportable and reusable. Plastic has gradually replaced natural products like metal, wood and fibres and somehow conserved the natural resources. As every coin has two sides, so plastic also has its pros and cons. It does not decompose and it is resistant to the natural disintegration processes and thus persists. It releases numerous toxic compounds which pollute land, ponds, streams, canals, lakes, rivers, oceans and leaches to the underground water through soil upon decomposition over a period of time. Plastic has also been found in the guts of many animals like goats, buffaloes, cows, deer and aquatic organisms suffered to death from ingestion of plastic debris or entanglement. Toxic gases, such as carbon monoxide, phosgene, chlorine, sulphur dioxide, as well as deadly furans and dioxins are released to the air if plastic is burnt irresponsibly. Today plastic pollution is the worst nightmare of the world. All human beings now have love-hate relationships with this fascinating material. It requires global attention and immediate action towards its handling and management. The poor management of this multipurpose product made it a curse for the society. In developing countries, poor management of plastic waste causes volumes plastics being mixed into watercourses and finally carried out to water reservoirs. Dumping of plastic waste is a thought-provoking issue of concern in India. Novel innovative methods have been employed to reduce adverse effects on the environment. Plastic can be degraded via a number of mechanisms, i.e. photo-oxidation, biodegradation, chemical and thermal. Some plastics may require several decades for the degradation depending upon their molecular structures [3 - 9].

\section{Classification of plastics}

(A) Plastics can be grouped into three types based on their thermal behaviour:

- Thermosets: Thermosetting plastics are very hard and tight-meshed, branched chain molecular structure. Once shaped, thermosets cannot be softened or remoulded, even if reheated; e.g. phenol formaldehyde (PF) or bakelite, epoxide (EP), polyurethane (PU), unsaturated polyester resins (UP), polytetrafluoroethylene (PTFE).

- Thermoplastics: They have a linear or branched structure and are flexible at ordinary temperature. Their molecular structure determines their strength and thermal behaviour. They do not undergo any chemical change on heating hence they can be reshaped again and again. They become soft on heating and hard again on cooling; e.g. polypropylene (PP), polyethylene terephthalate (PET), polythene (PE), polycarbonate (PC), poly-vinyl chloride (PVC), acrylonitrile butadiene styrene (ABS), polystyrene (PS), polymethyl methacrylate (PMMA), expanded polystyrene (EPS).

- Elastomers: These plastics have a cross linked structure with looser mesh than thermosets. They are elastic in nature. Once shaped, elastomers cannot be reshaped again upon heating; e.g. automobile tyres.

(B) Based on their size:

- Micro plastics - size less than $5 \mathrm{~mm}$ in diameter.

- Meso plastics - size ranges between 5 and $20 \mathrm{~mm}$ in diameter.

- Macro plastics - having size greater than $20 \mathrm{~mm}$ in diameter. 


\section{Sources of plastic wastes}

There are several sources which greatly contribute to plastic waste generation (shown in Figure 1), and different plastic-consuming sectors in India are given in Table 1.

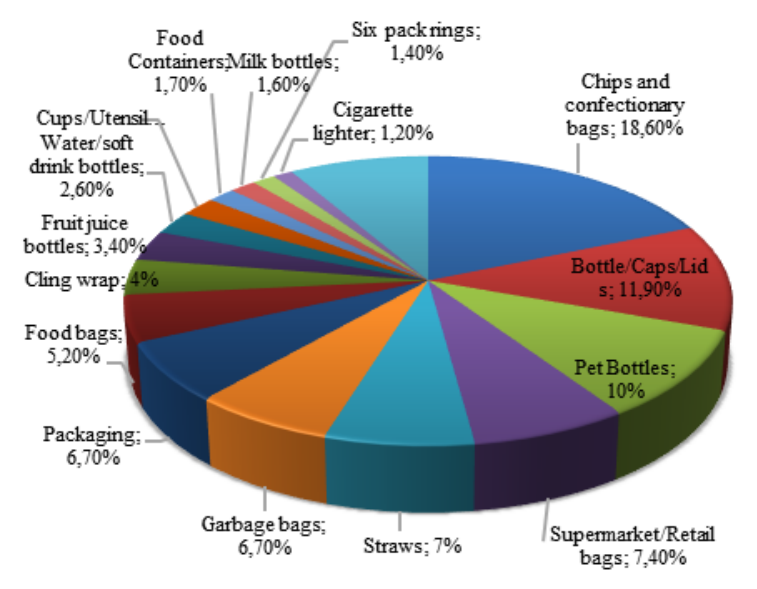

Figure 1. Sources of plastic waste generation

Table 1. Consumption of plastic in India by different sectors

\begin{tabular}{|c|c|}
\hline $\begin{array}{c}\text { Plastic consumption by } \\
\text { different sectors }\end{array}$ & Percentage \\
\hline Packaging & $42 \%$ \\
\hline Consumer products & $24 \%$ \\
\hline Building and construction & $14 \%$ \\
\hline Industrial goods & $13 \%$ \\
\hline Others & $7 \%$ \\
\hline
\end{tabular}

\section{Effects of plastic waste}

The adversity of plastic waste lies in the unplanned dumping and disposal of plastic waste. It affects not only the aesthetics and hygiene of the area but also has a negative impact on the natural environment by creating complications for plants, wildlife, and human population. Plastic wastes clog the drain passage and sewer network. They release a lot of contaminants into water bodies and pollute them. Intestine of animals may be choked due to ingestion of plastic into their stomach. They retard the plant growth as they interrupt the absorption of nutrients and water from soil. They also emit volatile organic carbon when disposed in landfills and decrease the soil fertility. Toxic gaseous pollutants, like carcinogenic dioxins and furans are released into the environment, while plastic incineration causes various diseases in human beings, such as cancer, ulcer, birth defects, respiratory diseases, thyroid problems etc. [10 - 12].

\section{Plastic waste management}

The plastic production is estimated to increase by $3.8 \%$ every year till 2030 worldwide. India produces 15 million tonnes of plastic waste every year but it is very difficult to handle the post-consumer waste due to lack of a functioning solid waste management system. The goal could effortlessly be achieved without any doubt if all packaging were made up of biodegradable material like paper or wood-based materials. But plastic has been governing continuously all the products, especially in the food packaging sector due to being a moisture-proof, impermeable, airtight and hygienic material. Thus, global measures have been undertaken for the development of eco-friendly, emerging plastic management systems using green chemistry principles with safe and compatible disposal methods. We need to expand, explore and execute the possible range of options for keeping this plastic waste out of landfill [13 - 15]. The most potential and emerging approach is "plastic to energy", which converts the chemical energy stored in plastic waste into fuel energy which can be utilized for the various purposes [16]. The different methods to manage the plastic waste are discussed below.

\section{Disposal methods}

\section{Landfilling}

Landfills are engineered constructions for containment and disposal of waste material to avoid contamination of the environmental dimensions [17]. All types of plastics can be disposed in landfills. Properly designed and operated sanitary landfills may be the best method for disposal of the plastic wastes. All recyclable materials can also be separated 
before the final closure of any sanitary landfill. The land can be reclaimed and used as a green park after completion of the landfill. There may be confined landfills that are not close to human habitation and farmland and can be securely used in an eco-friendly way to generate energy that can support the needs of the facility and the local residents. The methane and carbon dioxide exuding from these landfills can be harnessed to generate power. This also diminishes the quantum of the waste disposed in landfills. If landfills are not designed and operated properly, the emissions of landfill gases may give rise to greenhouse effects, bad odours and drastic health conditions. Improper lining of landfill layers allows the leachate to penetrate the sub soil and pollute the underground water. Since it needs a lot of space, this is considered as a highly wasteful method in the countries where there is a shortage of land for food production and lodging. Most of the plastics are impervious to microbial attack and persist in the environment for a long period of time. Plastics in landfill pits undergo different processes, like biodegradation, chemical degradation, photodegradation and thermal degradation. When plastics decompose in landfills trenches, they leak and add pollutants (bisphenol A and phthalates) into the soil and surrounding environment. Economically, landfill is the best suitable option, but it may be questioned whether the disposal of polymeric waste in landfills can be a component of reliable plastic waste management.

\section{Recycling}

Recycling is a promising and feasible technique to deal with the problem of plastic waste. Its efficiency is highly dependent on community awareness economic viability. Several plastics can be recycled and the recovered materials can be moulded again and again. However, this method cannot be successfully implemented due to complications while collecting and separating plastic waste. It is a blend of many techniques for converting waste plastics into secondary raw materials. Recycling is the process of recovering the product from heaps of wastes and reusing it again and again. It belongs to any activity including reuse, reclamation and recovery of materials or articles. This may be physical or primary, mechanical or secondary, chemical or tertiary, thermal or quaternary [18 - 20]. Nowadays valorisation term is used for embracing energy from waste (EfW) [21].

It is not similar to reuse, since the waste plastic materials cannot be claimed for remanufacturing. The recycling processes require the public participation for the segregation of the waste material at the source. Due to chemical properties of plastics, the recycling of plastic wastes also faces some technical challenges and complications [19]. Proper collection and sorting of plastic waste add more efficacy to recycling methods [20]. Plastics encompass an extensive range of resins having diverse chemical characteristics. Thermoplastics can be reformed into a fresh new product upon applying pressure and heat. The major portion of used plastics belongs to this category. Thermoset plastics cannot be remoulded upon applying heat and pressure. The different approaches used for recycling of plastic waste are given in Figure 2 and discussed as following.

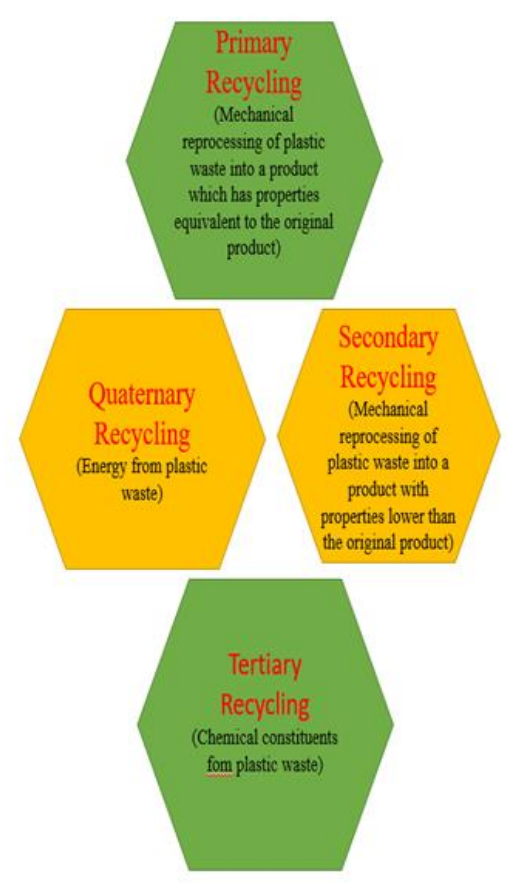

Figure 2. Recycling technologies for plastic waste 
a) Reuse

To use an item again after it has been utilized once is reuse. This comprises conventional reuse where the item is used again for the same function. Without reprocessing, reuse helps in saving time, resources, energy and money. It is the simplest way of recycling. For example, plastic based drinks and water bottles can be reused as same as glass-based bottles. But this method only works well for welldefined, simple, easily recognizable and separable items. The collection expenses and proper cleaning must be considered meticulously. The making of a new product by utilizing more energy and money via recycling a used bottle may not be a particularly useful approach.

\section{b) Primary or physical recycling}

It is the process in which less contaminantcontaining scrap materials are recycled for producing products with similar characteristics, such as remoulding. Only homogeneous or well sorted waste plastic can be recycled using this course of action, while it is not suited for multi-layered and heterogeneous mixed plastic wastes [21]. It conserves energy in huge amounts and reconverts the less contaminated plastic waste into its original basic resin form or pellet. The recycled versions contain properties same as of the original ones. It is also termed as closed loop recycling, which transforms one thing into more of the same thing. Recycling of aluminium soda cans is one of the examples because aluminium can be recycled to form new cans without degrading material and generating waste.

\section{c) Secondary or mechanical recycling}

Mechanical recycling is used for melting down the homogeneous old plastic material and then it can be used to manufacture new products having different characteristics from original plastic waste materials. This process is employed for a few times till the polymers break down and the quality aspects of the plastic deteriorates. We certainly cannot use mechanically recycled plastic polymers to recreate the same product but only to make something different out of it. This process is often called as downcycling. When discarded materials are converted into products of equivalent or greater value, it is said to be upcycled. When waste materials are transformed into products of lesser value, it is said to be upcycled. It is mostly operated at the temperature of $200-300{ }^{\circ} \mathrm{C}$. It is the simplest and the most inexpensive method. The steps include cutting, shredding, contaminants separation, floatation extrusion, and palletisation. The problems in this method are chiefly linked to the deprivation of recyclability and heterogeneity of waste plastic materials. Tyre recycling is a standard example of secondary recycling. It is not primary recycling, as a majority of recycled tyres do not end-up as new tyres but they can be turned into other rubbery products.

\section{d) Tertiary or feedstock or chemical recycling}

Approximately $80 \%$ of total plastic waste generated nowadays cannot be recycled by means of primary and secondary recycling. Hence, tertiary recycling is the best suited method for disposal of the above said waste piles. This technique gives valuable products which may be used as energy resources without igniting the plastic waste. The process which reduces a polymer chemically to its basic monomeric unit and then it can ultimately be re-polymerized and reformed [22]. These monomers can be utilized as virgin material substitutes in manufacturing new plastic polymers (new plastic products). It is also known as feedstock recycling or depolymerisation. Energy recovery means recovering the energy by converting waste into usable heat, electricity or fuel employing different feasible techniques including pyrolization, gasification, anaerobic digestion, combustion, and landfill gas recovery. This chemical method comprises manufacturing of some chemicals and energy fuels from plastic waste scrap and it can be applied to all forms of plastic waste mountains containing multilayered polymeric plastics which cannot be 
recycled using first two recycling methods. There is a wide range of chemical recycling methods (plastic to energy/fuel) which are slightly cost-effective than mechanical recycling:

\section{- Pyrolysis}

Pyrolysis is the most common chemical recycling process employed for managing plastic wastes. Plastics are hydrocarbons that are made from petroleum, and they can be converted back to liquid fuel. It is a method where the waste is thermally and chemically destructed in the absence of oxygen which results into the formation of gaseous, liquids and solids fractions. It is an endothermic process that involves thermal cracking and condensation reactions. Pyrolysis, sometimes called "plastics to fuel," converts nonrecyclable plastics from municipal solid waste into a synthetic crude oil that can be refined into gasoline, diesel fuel, heating oil or waxes. The main pyrolytic products generated are: i) gases: hydrogen, carbon monoxide, methane and carbon dioxide, ii) liquid: tar oil containing predominantly acetone, acetic acid, methyl alcohol, iii) solid: char comprising almost pure carbon with few inert constituents. Pyrolysis is done at three different temperatures to get different products:

- Low: Done at 400 - $500{ }^{\circ} \mathrm{C}$; e.g. thermochemical conversion of polyethylene and polypropylene produces gases and waxes coupled with hydrocarbon mixture possessing high calorific values. These gaseous fractions can be used again as feedstock.

- Medium: Operated at $500-700{ }^{\circ} \mathrm{C}$.

- High: Greater than $700{ }^{\circ} \mathrm{C}$; e.g. PP and $\mathrm{PE}$ produce olefin mixture at higher temperatures which can play an important role in the production of polyolefins. On the other hand, extreme pyrolysis yields carbon as the residue and the process is called carbonization [23 - 27].

\section{- Hydrocracking}

Hydrocracking is a two-step process, a combination of catalytic cracking and hydrogenation. Heavier feedstocks are split in the presence of hydrogen to yield more desirable products. This process requires hydrogen, a catalyst (a crystalline mixture of combination of silica-alumina with a uniform distribution of rare earth metals like Pt, $\mathrm{Pd}, \mathrm{W}$, and $\mathrm{Ni}$ within the crystalline lattice), high pressure and temperature. The catalytic cracking is endothermic while hydrogenation is exothermic in nature. Plastic waste is fragmented into hydrocarbons under hydrogen $\left(\mathrm{H}_{2}\right)$ environment at temperatures 290 to 400 ${ }^{\circ} \mathrm{C}$ and pressure $8.3-13.8 \mathrm{MPa}$ [28]. It gives a better feedstock than gasification and pyrolysis, quite similar to crude oil in composition and appearance. The disadvantages associated with this method are higher catalyst attrition and therefore higher catalyst consumption, higher capital costs for equipment installation, higher operating temperatures and pressures as well as sediment formations.

\section{- Solvolysis (dissolution)}

It is used to break down (depolymerise) certain types of plastic waste materials like expanded polystyrene (EPS)/Styrofoam into monomers with the help of some solvents, such as glycolysis, aminolysis, alcoholysis, hydrolysis, acidolysis and methanolysis. Approx. $97 \%$ ethylene, methyl methacrylate and styrene monomers can be retrieved from polyethylene (PE), polymethyl methacrylate (PMMA) and polystyrene (PS) respectively [17]. These solvolytic techniques fall under the categories of tertiary or chemical recycling options.

\section{- Catalytic cracking}

The thermal cracking in the presence of a catalyst can improve the conversion process and product quality. Previous studies have been conducted on pure polyolefins, pure acid catalysis and mainly zeolites. The catalyst significantly reduces the reaction times and destructing temperatures resulting in higher 
conversion rates and gaseous product yield. The catalytic cracking of the low-density polyethylene by using zeolite $\mathrm{Y}$ has proved its efficiency as a rich source for the manufacturing of a number of chemicals and a better alternative to the production of automobile fuels. The characterization of liquid products showed carbon chains of C8 C29 and they can be conserved as an alternative to fossil fuels for better sustainable, greener and cleaner environment [29 - 31]. Flow reactors are mostly used in the laboratory experimental set-up for these studies. There are two distinct modes of catalyst to contact. The first one is a liquid phase contact and the other is a vapour phase contact. The catalyst is contacted with melted plastic in liquid phase contact and acts upon partially disintegrated oligomers from long polymer chains, while the polymer is thermally broken down into hydrocarbon vapours which then get combined with the catalyst in vapour phase.

\section{- Gasification}

Gasification turns non-recyclable materials from municipal solid waste into a synthesis gas or syngas, which can be utilized for energy generation or converted into fuel or chemical feedstock like ethanol and methanol, which can be further used to produce a few other consumer products. It converts plastics into a mixture of 25 to $30 \%$ hydrogen, 30 to $60 \%$ carbon monoxide, 0 to $5 \%$ methane, 5 to $15 \%$ carbon dioxide, and trace amounts of other gases at high temperatures $\left(>700{ }^{\circ} \mathrm{C}\right)$, with a little exposure (controlled amount) to oxygen and/or steam without combusting the material. The vitrified slag or by-product slag can be used as construction material (in concrete or decorative tiles) [32 - 37]. It is very efficient method for waste to energy and can handle the mixed wastes easily but it requires high capital costs and technology still not established in terms of economics.

e) Quaternary recycling/incineration with energy recovery/thermal recovery

Incineration is thermal destruction of any waste material. It has been generally used for waste disposal but there is a growing public concern over the paybacks of burning the plastic waste versus the potential health risks from contaminants emitted during combustion. The open burning or uncontrolled incineration of waste is the easiest, the oldest and the cheapest method to get rid of the discarded materials. It requires less land, reduces waste volumes and disposes a huge amount of waste immediately without waiting for time consuming biodegradation process with less efforts. The emissions from combustion mainly comprises carbon monoxide, sulphur oxides, nitrogen oxides, hydrochloric acid, volatile organic compounds, trace amounts of poisonous chemical such as styrene, benzene, dioxins, formaldehyde, furans, polychlorinated biphenyls (PCBs), heavy metals like lead, mercury and arsenic etc., all of which can severely impact the entire population of this planet. The open burning emissions are directly inhaled or settle on the ground as droplets or fine particles, because burning of waste piles often does not end with full combustion of waste and thus produces particulate pollution.

Nowadays, incinerators are used to reduce the large volumes of waste piles. Modern incinerators use elevated temperatures, controlled air and outstanding mixing to alter the physical / chemical / biological characteristics/composition of waste materials. These new systems are embedded with efficient air pollution control devices to seize particulates and gaseous emissions for controlled combustion. Still there are so many health concerns associated with these systems, especially for people living nearby incinerators. The poorly designed incinerators release some toxic compounds, e.g. chlorinated dioxins and furans, into the environment; therefore, they face strong opposition and ire from various nongovernment organizations and nature lovers. Since municipal wastes contain plastics, many countries do not give permission for these wastes to be incinerated. Combustion of plastic waste causes negative effects on environment and health as dangerous substances are released into the atmosphere 
during the process. These harmful emissions may be carcinogenic and cause respiratory disorders, hormonal imbalance, abnormal heartbeats, heart attacks, allergic hypersensitivity, nervous system disorders, asthma attacks, and shortness of breath as well. Polyvinyl chloride (PVC) pipes, shoe soles, rexine, polystyrene (thermocol) disposable cups, plastic spoons, and halogenated additives upon combustion generate persistent organic contaminants known as furans, dioxins and polychlorinated biphenyls, which are then released into the environment. Dioxins and furans from unsegregated waste smoke settle on crops and end up in our food. The burning of polyethylene (PE), polyurethane (PU), and polystyrene (PS) releases poisonous compounds that may cause immune disorders, lung ailments such as lung ulceration and irritation which cut oxygen supply to the heart. Styrene gas in excess can cause death. The vapour can cause irreparable damage to eyes and mucous membranes. These are the reasons for witnessing a spike in cases of certain cancers, heart disease and several other serious health disorders [38 - 45].

Energy recovery is extremely resourceefficient solution rather than landfilling or enforced recycling for the plastic wastes. Incineration with energy recovery is the one of various waste-to-energy state-of-the-art technologies. All polymers are long-chain carbon-containing compounds having a high heat content and therefore a high calorific value. The energy content can be recovered upon combustion of waste materials/scrap plastics at $900-1100{ }^{\circ} \mathrm{C}$. It is the utmost convenient and effective means to minimise the volume of solid waste. The hydrocarbon constituents of the combustible residue mix with oxygen to produce carbon dioxide, water and inert residue with oxides of metals and minerals during incineration. When plastics are incinerated, they generate hydrochloric acid along with carbon dioxide and water. A certain amount of $\mathrm{HCl}$ is neutralized by basic nature of inert ash. Corrosion due to $\mathrm{HCl}$ can be reduced by adding lime to refuse. Dioxins, furans and poly aromatic hydrocarbons
(PAHs) are also produced at $300{ }^{\circ} \mathrm{C}$. Polymers can be completely combusted or chemically degraded at $700-900{ }^{\circ} \mathrm{C}$. Since plastics are made from petroleum, coal, and natural gas, they have a higher stored energy value than any other material generally found in the waste stream. The key aspect of this process is only to destroy the waste and keep it out of landfills. This technology converts the chemical energy into thermal energy. The heat released from incineration can be used to produce steam to run a turbine and generate electricity.

A few plastic resins which can be converted into various useful recyclable forms are tabulated in Table 2.

\section{Biodegradation}

All plastics can be disintegrated naturally but they may take decades or even centuries for biodegradation. Biodegradation is the natural process in which biodegradable plastics can be decomposed into carbon dioxide, water and biomass by the action of living microorganisms. They require a humid environment with an enormous supply of oxygen, aerobic micro-organism, $\mathrm{pH}$ and temperature for the break down. They can also take up several months or even years while decomposing in landfills in absence of any necessary requirement as insufficient supply of oxygen. The biodegradability of a plastic is directly linked with the chemical properties of the polymer and does not depend upon the feedstock source. Biodegradable plastics can be either petroleum-based or bio-based. Biodegradable plastic is often used in packaging of organic fruits, vegetables and groceries in supermarkets. The logo of a sprouting leaf on biodegradable plastic materials defines that the material must deteriorate completely within 7 weeks in an industrial composting unit at $65{ }^{\circ} \mathrm{C}$. These plastics have the potential to resolve the ambiguity of waste management, particularly for disposable packaging that cannot be easily segregated from organic waste [46 - 48]. 
Table 2. Recycling of plastics with SPI codes into various useful recyclable forms

\begin{tabular}{|c|c|c|c|}
\hline Plastic resin & Uses & Identification code & Recyclable forms \\
\hline $\begin{array}{l}\text { Poly ethylene } \\
\text { terephthalate } \\
\text { (PET) }\end{array}$ & $\begin{array}{l}\text { Water and juice bottles, biscuit } \\
\text { trays }\end{array}$ & & $\begin{array}{l}\text { Textiles, pillow fillings, carpets, life-saver } \\
\text { jackets, storage jars and containers, boat } \\
\text { sails, clothing, automobile parts, shoes, } \\
\text { sleeping bags, luggage, winter jackets and } \\
\text { coats, polar fleece, fibres, tote bag, } \\
\text { furniture, straps, bottles and food } \\
\text { containers. } \\
\end{array}$ \\
\hline $\begin{array}{l}\text { High density } \\
\text { polyethylene } \\
\text { (HDPE) }\end{array}$ & $\begin{array}{l}\text { Ice cream tubs, milk bottles and } \\
\text { jugs, shampoo and cleaning agent } \\
\text { bottles, freezer bags. }\end{array}$ & & $\begin{array}{l}\text { Plastic crates, lumber, fencing, laundry } \\
\text { liquid detergent bottles, oil cans and bottles, } \\
\text { pens, recycling containers, floor tiles, } \\
\text { drainage pipes, benches, pet houses, } \\
\text { foldable and portable tables, shampoo } \\
\text { bottles. }\end{array}$ \\
\hline $\begin{array}{l}\text { Polyvinyl chloride } \\
\text { (PVC) }\end{array}$ & $\begin{array}{l}\text { Pipes, cooking oil bottles, } \\
\text { teethers, toys, computer cables, } \\
\text { plastic pipes, plumbing materials, } \\
\text { window frames, garden hoses. }\end{array}$ & & $\begin{array}{l}\text { Flooring, mobile home skirting, decks, } \\
\text { panelling, mud flaps, roadway gutters, } \\
\text { cables, speed breaker bumps, mats. }\end{array}$ \\
\hline $\begin{array}{l}\text { Low-density } \\
\text { polyethylene } \\
\text { (LDPE) }\end{array}$ & $\begin{array}{c}\text { Shrink wraps, clothing, furniture } \\
\text { bags, trays, dry cleaner garment } \\
\text { bags, grocery wrappers, } \\
\text { containers, food packaging film, } \\
\text { squeezable bottles. }\end{array}$ & & $\begin{array}{l}\text { Garbage cans, lumber, trash cans and can } \\
\text { liners, composting bins, panelling, shipping } \\
\text { envelopes, floor tiles. }\end{array}$ \\
\hline $\begin{array}{l}\text { Polypropylene } \\
\text { (PP) }\end{array}$ & $\begin{array}{l}\text { Potato chip bags, microwave } \\
\text { utensils, packaging tape, pails, ice } \\
\text { cream and yogurt tubs, bottle caps } \\
\text { straws and ropes. }\end{array}$ & & $\begin{array}{l}\text { Ice scrapers, rakes, battery cables, signal } \\
\text { lights, battery cables, brushes, brooms, auto } \\
\text { battery casings, landscape borders, bicycle } \\
\text { racks, trays. }\end{array}$ \\
\hline $\begin{array}{l}\text { Polystyrene (PS) / } \\
\text { Expanded } \\
\text { polystyrene (EPS) } \\
\text { / Styrofoam }\end{array}$ & $\begin{array}{l}\text { Protective foam packaging for } \\
\text { furniture and electronics, } \\
\text { disposable Styrofoam hot drink } \\
\text { cups/ Cutlery, plates, cups and } \\
\text { egg cartons. }\end{array}$ & & $\begin{array}{l}\text { Insulation, license plate frames, light } \\
\text { switches and plates, egg cartons, rulers, } \\
\text { foam packaging, carry-out containers. }\end{array}$ \\
\hline $\begin{array}{l}\text { Others (Bisphenol } \\
\text { A-BPA, PC- } \\
\text { Polycarbonate, } \\
\text { Lexan, Polyamide, } \\
\text { Polyacrylonitrile, } \\
\text { Bioplastic) }\end{array}$ & $\begin{array}{l}\text { Water cooler bottles, sippy cups } \\
\text { baby bottles and car parts. }\end{array}$ & & $\begin{array}{l}\text { Plastic lumber used in outdoor railings, } \\
\text { decks, moulding, park benches, custom- } \\
\text { made products. }\end{array}$ \\
\hline $\begin{array}{l}\text { Biodegradable } \\
\text { plastics }\end{array}$ & $\begin{array}{l}\text { Disposable materials, such as } \\
\text { packaging, cutlery, crockery and } \\
\text { food service containers. }\end{array}$ & & $\begin{array}{l}\text { Recyclable but not economically } \\
\text { recyclable. }\end{array}$ \\
\hline $\begin{array}{l}\text { Acrylonitrile } \\
\text { butadiene styrene } \\
\text { (ABS) }\end{array}$ & $\begin{array}{l}\text { Toys, musical instruments, TV } \\
\text { cabinets, mobile phones, } \\
\text { calculators, plastic, automobile } \\
\text { bumpers and auto parts, aircraft } \\
\text { and aerospace materials, luggage } \\
\text { casings, protective items such as } \\
\text { helmet, golf clubs, chairs, tables, } \\
\text { containers, etc. }\end{array}$ & ABS & $\begin{array}{c}\text { It can be recycled by using "forth flotation" } \\
\text { process. } 99 \% \text { of ABS plastic can be } \\
\text { recovered using water streams from a } \\
\text { mixture of plastics. }\end{array}$ \\
\hline
\end{tabular}

Plastics with codes 1, 3, 6 and 7 designated by Society of the Plastics Industry (SPI) must be avoided for any useful purposes as they release some harmful chemicals which may contaminate the products and make them poisonous and carcinogenic. 


\section{ALTERNATE VIABLE METHODS FOR PLASTIC WASTE MANAGEMENT}

The utilization of plastic materials is a challenging issue for environmental safety. All used up plastics become waste and require vast amount of land areas for storing because many tonnes of plastic waste cannot be entirely recycled at once. Slow biodegradability and gigantic quantities of plastic waste adversely affect the environment. In lieu of plastic waste management, a new approach to deal with the plastic problem has been introduced in which different types of plastic waste have been fused in concrete to deter the direct interaction of plastic materials with the environment because concrete has a feasible service life. No solid residues or ashes and toxic gases are produced during the process [49]. The plastic waste disposal in landfills is quite obnoxious due to low biodegradability of few polymers, law policies and several other reasonable directives. The civil engineering department has handled this problem in an appropriate sustainable manner by using mammoth amount of polyethylene terephthalate (PET) wastes in concrete as a constituent providing increase in durability, strength etc. [50, 51]. The fine fly ash emitted with flue gas has been proven a very effective infill material, which, combined with coarse grit or pebbles, generates a composite material having better load carrying capacity. It was also confirmed that consumed plastic bottles having different characteristics can act as a perfect compression additive when used with suitable infill materials [52]. Some studies have revealed the properties and usage of bakelite as a building material in paver blocks, bricks and solid blocks with proper specifications. The consumption of waste material in construction industry is a challenging task. Integration of plastic wastes in construction material gives a cost effective and light weight sustainable element which enhances the strength and durability of the material. Waste bakelite was used for fine and coarse aggregate in order to reduce plastic disposal problems [53]. To fight against the single-use plastic pollution, some brands like Raw Pressery, a cold pressed juice brand, are opting for sustainable innovative measures to reduce the plastic waste production. The used plastic bottles are washed, cut into pieces, melted, formed into chips, extruded into yarn, woven into fabric and then dyed. This whole process ends up with the ocean friendly, wrinkle free t-shirts. The company has set an example for other companies to mitigate plastic pollution through recycling or upcycling [54]. The plastic waste usage in road construction came into light by employing different effective and viable methods to reconsume the plastic waste particles in hard-plastic waste as a bitumen modifier primarily for flexible pavements like bitumen and bituminous concrete roads. It not only improves the service life and pavement performance but also saves bitumen usage in road construction significantly. This process is definitely eco-friendly. These developments are of high social and ecological importance, contributing to sustainable development. Two processes i.e. wet process and dry process are employed for combining the plastic in surface layer of the road. This can be helpful in managing waste plastic along with improving road quality and making them reasonable too [55 - 60]. Eastman's innovated advanced circular recycling technology that breaks down polyester waste into monomers which cannot be recycled by using current mechanical methods, delivering a true circular solution. Another carbon renewal technology was introduced, which can recycle few of the most complex plastic waste, including non-polyester plastics and mixed plastics that cannot be recycled with conventional recycling technologies. This technology uses plastic wastes as feedstock and converts them into molecular components. This process partly oxidizes the waste plastic and, at a very high efficiency, converts it into the basic building blocks of certain Eastman products, including advanced materials and fibers segment products that serve in ophthalmics, durables, packaging, textiles and nonwovens end-use markets [61]. The waste plastic bags can be used in a better way by designing the tiles with lessened flammability, improved mechanical strength and increased resistance against strong acids, bases, and organic solvents. The non-biodegradability and prolonged durability 
of waste plastic bags make its disposal problematic. Plastic solid waste (PSW) serves challenges and opportunities to the civilization irrespective of technical escalations and alertness. Traditional and conventional disposal methods have failed to cope up with higher generation rates of plastic waste. Simultaneously fly ash, a waste by-product produced upon coal burning in thermal power plants poses a serious risk on environmental health. Waste plastic matrix reinforced with fly ash (FA) and a flame retardant using twin screw extruder are extruded and moulded into composite tiles [62, 63]. The plastic waste upcycling into graphene, a value-added product, involves a two-step pyrolysis process i.e. initially at $400{ }^{\circ} \mathrm{C}$ in presence of nanoclay followed by at $750{ }^{\circ} \mathrm{C}$ under nitrogen atmosphere resulting in the formation of a black charged residue. The synthesis of graphene nano sheets can be investigated and confirmed using TEM, FT-IR and EDX Raman spectroscopy [64 - 69].

One economical and novel method has been anticipated for synthesis of valuable silicon/carbon nanofibers/carbon ( $\mathrm{Si} / \mathrm{CNF} / \mathrm{C})$ composites for lithium-ion batteries using selfprepared micron-sized silicon and reutilizing high-density polyethylene (HDPE) waste as raw materials. Pyrolyzed carbon and carbon nanofibers obtained through pyrolysis act as a carbon-conductive network and confine the volumetric enlargement of $\mathrm{Si}$ during $\mathrm{Li}$-ion insertion/deinsertion processes [70]. It has been a key challenge to develop commercially favourable, bi-functional and highly active catalyst for the application of alkaline fuel cells. A composite fullerene iron oxide derived from mineral water waste plastic bottles was utilized as a promising electrocatalyst with bifunctional activity for electrodes in an alkaline fuel cell as a substitute of platinum [71]. Rubber and plastic waste can be used as possible sources of refused derived fuel (RDF) in cement industrial plants. Plastic waste generates $<2$ mass $\%$ ash content with high calorific values $(38.64 \mathrm{~kJ} / \mathrm{g})$ while rubber waste shows 21.2 mass $\%$ ash contents, with $36 \mathrm{~kJ} / \mathrm{g}$ calorific value. Reduction in setting times, an enhancement in compressive strength and acceleration of the hydration reactions can be attributed to the pozzolanic properties of RDF ash [72, 73]. Higher generation rates, treatment and disposal of industrial wastes have become a critical environmental problem. Approx. 7.4 million tonnes of hazardous waste annually are expelled from Indian industries which are the major factors in building the GDP and economy. Only 3.98 million tonnes waste is recyclable out of the waste generated for resource or energy recovery. The Netherlands is the highest consumer of hazardous waste $(83 \%)$ as raw material in cement kilns and alternative fuel, while India uses $1 \%$ waste only, which opens up a new horizon for the potential consumption of hazardous waste in our country. Uncontrolled waste management damages all three dimensions of environment, posing health risks to all the inhabitants of the planet. Generally, in most cases, industrial waste residues are disposed in landfills after incineration. So hazardous wastes can be consumed in the production of an alternative for fossil fuels and/or raw material in some industries [74]. Plastic lumber can be prepared from commingled waste plastics along with rubber powder as reinforcement and fly ash as filler material by using washing and shredding machine and two stage extruder-injection moulding machine. Different constructive and handy products, like chairs, tables, signposts, pallets, fences, barricades, benches and other outdoor furniture prepared from plastic lumber are durable, strong and economical, and diminishing the wood usage [75]. Large population and incompetent waste management increases the problems of some developing countries, like India, China and several other low and middle-income countries which generate waste in bulk. Waste to energy encompasses the interconversion of waste materials to energy and can be possibly achieved with less segregation and rinsing. It can be a futuristic feasible global prospect for plastic waste management $[76,77]$. Recycled macro plastic fibres (polypropylene) are extensively used up in concrete to boost its post-cracking performance and to inhibit shrinkage cracks. It also phases out the 
requirement of steel mesh in concrete, therefore reducing cost and labour time [78].

\section{CONTROL MEASURES FOR PLASTIC WASTE REDUCTION}

- Effective measures for plastic waste reduction.

- Minimize polymeric plastic waste generation.

- Reduce, reuse and recycle.

- Ban on single use plastic.

- Usage of feasible alternatives for plastics.

- Source segregation.

- Either use recyclable plastic materials or the layer thickness should not be less than $50 \mu \mathrm{m}$ according to rules formed by Ministry of Environment, Forest and Climate Change.

- Educating individuals in order to increase awareness and behavioural change.

- Conversion of plastic waste to energy or fuel on commercial scale for public consumption.

\section{CONCLUSION}

It is quite essential for mankind to use the natural resources responsibly and develop a sensible and ethical attitude towards environment for sustainable development of the future generations. Improper handling and inappropriate methods of plastic waste disposal are polluting the air, land, and water and adding toxic substances. In this paper various methods have been discussed for managing plastic waste. Some methods like open dumping, open burning, and landfilling have been discarded by several countries and are no longer considered as a viable green method in the present scenario. Recycling of plastics is one of the best suitable methods for reducing environmental impacts and resource depletion. Mechanical recycling turns the plastic waste scraps into new plastic materials by physical ways. The homogeneous waste stream can be recycled only by employing this method. For heterogeneous plastics, chemical recycling is mandatory. This recycling technique renovates the piles of plastic waste into a novel feedstock that can be further employed for different purposes needed so far in the service of society. Conversion of any kind of waste into useful energy is a highly studied and explored dimension that can be helpful in plastic waste management. Though the safety concerns and health risks related with their usage and large-scale production are not fully assessed and managed, plastic polymers possess a high calorific value due to their chemical compositions, so they can be combusted easily. Pyrolysis and gasification both are useful for chemical conversions at different temperatures. The main products of pyrolysis (char, pyrolytic oil, syngas, biofuel) find their application as alternative fuel sources. Char can find its utility in a diverse range of applications, such as soil enhancement and remediation, wastewater treatment, control of carbon emissions and animal food production, while the liquid product and syngas (synthetic gas) can be valorised into various chemicals. These methods have higher energy conversion potential and lesser toxic emissions as compared to open burning. However, these techniques still need advancements and developments in order to achieve commercialization. Further investigations are still needed to use the feedstock recycling. It is also expected to use different possible combinations of plastic waste disposal routes which can be explored as an effective, economically viable and environment-friendly solution for plastic waste management.

Furthermore, the aggregates of post-consumer plastic waste can be effectively used to substitute conventional aggregates as an alternate viable method for plastic waste management. When mixes in concrete it can reduce the overall bulk density. Recycled plastic materials can be used efficiently for repairing and overlaying of damaged cement concrete surfaces in floors, pavements, bridges and dams. These are also useful in recast 
applications like utility elements such as drainage components for acid wastes, sewer pipes, underground vaults and junction boxes, power line transmission poles, for transportation median barriers, bridge panels and railroad ties. Several efforts are also contributing towards the fabrication of materials resistant to marine environments by using plastic wastes. These materials can be environmentally superior and economically competitive to conventional products. This area needs much more attention and scientific research for the development of innovative methods to deal with the plastic waste piles.

\section{REFERENCES}

[1] I. Gestoso, E. Cacabelos, P. Ramalhosa, J. Canning-Clode, Plasticrusts: A new potential threat in the Anthropocene's rocky shores, Science of The Total Environment 687(2019), 413-415.

[2] I.E. Napper, R.C. Thompson, Marine plastic pollution: other than microplastic, in: Waste, A Handbook for Management, Second Edition, ed. T.M. Letcher, D.A. Vallero, Elsevier, 2019, 425-442.

[3] L. Lebreton A. Andrady, Future scenarios of global plastic waste generation and disposal, Palgrave Communications 5(2019), 6.

[4] R. Geyer, J.R. Jambeck, K.L. Law, Production, use and fate of all plastics ever made, Science Advances 3(2017) 7, e1700782.

[5] F. Alshehrei, Biodegradation of synthetic and natural plastic by microorganisms, Journal of Applied and Environmental Microbiology 5(2017), 819.

[6] E. Munir, R.S.M. Harefa, N. Priyani, D. Suryanto, Plastic degrading fungi Trichoderma viride and Aspergillus nomius isolated from local landfill soil in Medan, IOP Conf. Series: Earth and Environmental Science, $4^{\text {th }}$ International Conference on Friendly City 4 "From Research to Implementation for Better
Sustainability", IOP Publishing Ltd., 126, Medan, Indonesia, October 11-12, 2017, 012145.

[7] A. Paco, K. Duarte, J.P. da Costa, P.S.M. Santos, R. Pereira, M.E. Pereira, Biodegradation of polyethylene microplastics by the marine fungus Zalerion maritimum, Science of The Total Environment 586(2017), 10-15.

[8] N. Lucas, C. Bienaime, C. Belloy, M. Queneudec, F. Silvestre, J.E. NavaSaucedo, Polymer biodegradation: mechanisms and estimation techniques, Chemosphere 73(2008), 429-442.

[9] P.P. Vivek, Sustainable model of plastic waste management, International Journal of Chemtech Research 7(2014) 1, 440458.

[10] N. Laskar, U. Kumar, Plastics and microplastics: A threat to environment, Environmental Technology and Innovation 14(2019), 100352.

[11] W. Wang, H. Gao, S. Jin, R. Li, G. Na, The ecotoxicological effects of microplastics on aquatic food web, from primary producer to human: A review, Ecotoxicology and Environmental Safety 173(2019), 110-117.

[12] R.K. Patle, Environmental pollutants effects on human health, Journal Current Science 20(2019), 2.

[13] K. Rajendran, R. Lin, D.M. Wall, J.D. Murphy, Influential Aspects in Waste Management Practices, in: Sustainable Resource Recovery and Zero Waste Approaches, ed. M.J. Taherzadeh, K. Bolton, J. Wong, A. Pandey, Elsevier, 2019, 65-78.

[14] S. Singh, M. Mohanty, T. Mohanty, B.P. Mohapatra, Study the Kitchen Waste Management Practices in Rural Household, Current Journal of Applied Science and Technology 36(2019) 2, 17.

[15] P. Banerjee, A. Hazra, P. Ghosh, A. Ganguly, N.C. Murmu, P.K. Chatterjee, Solid waste management in India: a brief review, Waste Management and Resource Efficiency (2019), 1027-1049.

[16] H.H. Khoo, LCA of plastic waste recovery into recycled materials, energy 
and fuels in Singapore, Resources, Conservation and Recycling 145(2019), 67-77.

[17] Y. Aryan, P. Yadav, S.R. Samadder, Life Cycle Assessment of the existing and proposed plastic waste management options in India: A case study, Journal of Cleaner Production 211(2019), 12681283.

[18] K. Ragaert, L. Delva, K. van Geem, Mechanical and chemical recycling of solid plastic waste, Waste Management 69(2017), 24-58.

[19] J. Hopewell, R. Dvorak, E. Kosior, Plastics recycling: challenges and opportunities, Philosophical Transactions of the Royal Society B: Biological Sciences 364(2009) 1526, 2115-2126.

[20] N. Singh, D. Hui, R. Singh, I.P.S. Ahuja, L. Feo, F. Fraternali, Recycling of plastic solid waste: A state of art review and future applications, Composites Part B: Engineering 115(2017), 409-422.

[21] S.M. Al-Salem, P. Lettieri, J. Baeyens, The valorization of plastic solid waste (PSW) by primary to quaternary routes: From re-use to energy and chemicals, Progress in Energy and Combustion Science 36(2010) 1, 103-129.

[22] A. Rahimi, J.M. García, Chemical recycling of waste plastics for new materials production, Nature Reviews Chemistry 1(2017) 6, 0046.

[23] R. Miandad, M. Rehan, M.A. Barakat, A.S. Aburiazaiza, H. Khan, I.M. Ismail, J. Dhavamani, J. Gardy, A. Hassanpour, A.S. Nizami, Catalytic pyrolysis of plastic waste: Moving towards pyrolysis based biorefineries, Frontiers in Energy Research 7(2019), 27.

[24] A. Mohan, S. Dutta, V. Madav, S.S. Bhushnoo, J. Fernandez-Garcia, P.T. Williams, Co-pyrolysis of scrap tire and plastic using coal derived flyash, Proceedings book of the $27^{\text {th }}$ European Biomass Conference and Exhibition (EUBCE-2019), Lisbon, Portugal, May 27-30, 2019, 501-1506.

[25] K. Ding, S. Liu, Y. Huang, S. Liu, N. Zhou, P. Peng, Y. Wang, P. Chen, R.
Ruan, Catalytic microwave-assisted pyrolysis of plastic waste over $\mathrm{NiO}$ and $\mathrm{HY}$ for gasoline-range hydrocarbons production, Energy Conversion and Management 196(2019), 1316-1325.

[26] S.V. Kulkarni, Y. Shastri, Economic Analysis and Life Cycle Assessment of Pyrolysis of Plastic Waste in Mumbai, India, in: Sustainable Waste Management: Policies and Case Studies, ed. S. Ghosh, Springer, Singapore, 2020, 453-463.

[27] R. Palos, A. Gutiérrez, F.J. Vela, J.A. Maña, I. Hita, A. Asueta, S. Arnaiz, J.M. Arandes, J. Bilbao, Assessing the potential of the recycled plastic slow pyrolysis for the production of streams attractive for refineries, Journal of Analytical and Applied Pyrolysis 142(2019), 104668.

[28] L. Hauli, K. Wijaya, A. Syoufian, Hydrocracking of LDPE plastic waste into liquid fuel over sulfated zirconia from a commercial zirconia nanopowder, Oriental Journal of Chemistry 35(2019) 1, 128-133.

[29] S. Streiff, M. Piccinini, E. Marx, A. Corma, M. Cerro-Alarcón, J. Mengual, S.A. Solvay, Process for converting mixed waste plastic into liquid fuels by catalytic cracking, U.S. Patent Application 16/062, 702, 2019.

[30] J. Socci, A. Osatiashtiani, G. Kyriakou, T. Bridgwater, The catalytic cracking of sterically challenging plastic feedstocks over high acid density Al-SBA-15 catalysts, Applied Catalysis A 570(2019), 218-227.

[31] S. Streiff, D. Balthasart, M. Piccinini, M. Garrait, A. Corma, M. Cerro-Alarcón, J. Mengual, S.A. Solvay, Process for converting plastic into waxes by catalytic cracking and a mixture of hydrocarbons obtained thereby, U.S. Patent Application 16/089, 468, 2019.

[32] S.A. Salaudeen, P. Arku, A. Dutta, Gasification of plastic solid waste and competitive technologies, Plastics to Energy: Fuel, Chemicals and Sustainability Implications, $1^{\text {st }}$ Edition, William Andrew Publishing, Norwich, 
New York, United States, 2019, 269293.

[33] N. Emad, B. Vahid, Hydrogen production from co-gasification of asphaltene and plastic, Petroleum Science and Technology 37(2019) 16, 1905-1909.

[34] Y. Chai, N. Gao, M. Wang, C. Wu, $\mathrm{H}_{2}$ production from copyrolysis/gasification of waste plastics and biomass under novel catalyst $\mathrm{Ni}$ $\mathrm{CaO}-\mathrm{C}$, Chemical Engineering Journal 382(2020), 122947.

[35] H. Hofbauer, M. Materazzi, Waste gasification processes for SNG production, Substitute Natural Gas from Waste: Technical Assessment and Industrial Applications of Biochemical and Thermochemical Processes, $1^{\text {st }}$ Edition, Academic Press, London, United Kingdom, 2019, 105-160.

[36] M.T. Munir, I. Mardon, S. Al-Zuhair, A. Shawabkeh, N.U. Saqib, Plasma gasification of municipal solid waste for waste-to-value processing, Renewable and Sustainable Energy Reviews 116(2019), 109461.

[37] M. Inayat, S.A. Sulaiman, J.C. Kurnia, M. Shahbaz, Effect of various blended fuels on syngas quality and performance in catalytic co-gasification: A review, Renewable and Sustainable Energy Reviews 105(2019), 252-267.

[38] C.I. Idumah, I.C. Nwuzor, Novel trends in plastic waste management, $\mathrm{SN}$ Applied Sciences 1(2019) 11, 1402.

[39] A. Hussain, A. Bhattacharya, A. Ahmed, Plastic waste pollution and its management in India: A review, Advanced Treatment Techniques for Industrial Wastewater, $1^{\text {st }}$ Edition, IGI Global publishing, Hershey, Pennsylvania, 2019, 62-73.

[40] M. Heidari, P.P. Garnaik, A. Dutta, The Valorization of Plastic Via Thermal Means: Industrial Scale Combustion Methods, Plastics to Energy: Fuel, Chemicals and Sustainability Implications, $1^{\text {st }}$ Edition, William Andrew Publishing, Norwich, New York, United States, 2019, 295-312.
[41] W. Wang, N.J. Themelis, K. Sun, A.C. Bourtsalas, Q. Huang, Y. Zhang, Z. Wu, Current influence of China's ban on plastic waste imports, Waste Disposal and Sustainable Energy 1(2019) 1, 6778.

[42] M. Okan, H.M. Aydin, M. Barsbay, Current approaches to waste polymer utilization and minimization: A review, Journal of Chemical Technology and Biotechnology 94(2019) 1, 8-21.

[43] R.U. Duru, E.E. Ikpeama, J.A. Ibekwe, Challenges and prospects of plastic waste management in Nigeria, Waste Disposal and Sustainable Energy 1(2019), 117-126.

[44] S.M. Al-Salem, Major Technologies Implemented for Chemicals and Fuel Recovery, Plastics to Energy: Fuel, Chemicals and Sustainability Implications, $1^{\text {st }}$ Edition, William Andrew Publishing, Norwich, New York, United States, 2019, 21-44.

[45] O.A. Alabi, K.I. Ologbonjaye, O. Awosolu, O.E. Alalade, Public and Environmental Health Effects of Plastic Wastes Disposal: A Review, Journal of Toxicology and Risk Assessment 5(2019), 21.

[46] S. Yoshida, K. Hiraga, T. Takehana, I. Taniguchi, H. Yamaji, Y. Maeda, A bacterium that degrades and assimilates polyethylene terephthalate, Science 351(2016), 1196-1199.

[47] R. Wei, W. Zimmermann, Microbial enzymes for the recycling of recalcitrant petroleum-based plastics: how far are we? Microbial Biotechnology 10(2017), 1308-1322.

[48] F. Alshehrei, Biodegradation of Synthetic and Natural Plastic by Microorganisms, Journal of Applied and Environmental Microbiology 5(2017) 1, 8-19.

[49] M.B. Hossain, P. Bhowmik, K.M. Shaad, Use of waste plastic aggregation in concrete as a constituent material, Progressive Agriculture 27(2016) 3, 383391.

[50] S. Dutta, M.B. Nadaf, J.N. Mandal, An overview on the use of waste plastic 
bottles and fly ash in civil engineering applications, Procedia Environmental Sciences 35(2016), 681-691.

[51] R. Sharma, P.P. Bansal, Use of different forms of waste plastic in concrete - a review, Journal of Cleaner Production 112(2016), 473-482.

[52] B.K. Gupta, S. Singhb, To Study the feasibility of Coarse and Fine plastic Aggregates in Concrete, International Journal of Applied Engineering Research 13(2018) 8, 5815-5822.

[53] S.S. Sasmitha, R.N. Uma, A Critical Review on the Application of Bakelite as a Partial Replacement of Fine and Coarse Aggregate, International Journal for Science and Advance Research in Technology 4(2018) 11, 174-178.

[54] https://bestmediainfo.com/2019/06/rawpressery-launches-recycling-initiativeraw-cycle/, Accessed: February 21, 2020.

[55] P.N.A. Asare, F.A. Kuranchie, E.A. Ofosu, Evaluation of incorporating plastic wastes into asphalt materials for road construction in Ghana, Cogent Environmental Science 5(2019) 1, 1576373.

[56] P. Duggal, A.S. Shisodia, S. Havelia, K. Jolly, Use of Waste Plastic in Wearing Course of Flexible Pavement, in: Advances in Structural Engineering and Rehabilitation, ed. S. Adhikari, B. Bhattacharjee, J. Bhattacharjee, Lecture Notes in Civil Engineering, vol. 38. Springer, Singapore, 2020, 177-187.

[57] N. Usman. M.I.M. Masirin, Performance of asphalt concrete with plastic fibres, Use of Recycled Plastics in Eco-efficient Concrete, $1^{\text {st }}$ Edition, Woodhead Publishing, Sawston, Cambridge, 2019, 427-440.

[58] M.V Shahnawaz, M.K. Sangale, A.B. Ade, Plastic Waste Disposal and Reuse of Plastic Waste, in: Bioremediation Technology for Plastic Waste, Springer, Singapore, 2019, 21-30.

[59] G.G. Giwangkara, A. Mohamed, N.H.A. Khalid, H.M. Nor, M.R. Hainin, R.P. Jaya, W.N.H.M. Sani, C.R. Ismai, M.M.A. Aziz, Recycled concrete aggregate as a road base material, IOP Conference Series: Materials Science and Engineering, $11^{\text {th }}$ International Conference on Geotechnical Engineering in Tropical Regions (GEOTROPIKA), ed. H. Yaacob, et al., Institute of Physics Publishing (IOP), February 27-28, 2019, Kuala Lumpur, Malaysia, vol. 527, Paper: 012061, 111.

[60] I.A. El-Naga, M. Ragab, Benefits of utilization the recycle polyethylene terephthalate waste plastic materials as a modifier to asphalt mixtures, Construction and Building Materials 219(2019), 81-90.

[61] https://www.eastman.com/Company/Ne ws_Center/2019/Pages/Eastman-offerssecond-innovative-recyclingsolution.aspx, Accessed: February 21, 2020.

[62] R. Dhawan, B.M.S. Bisht, R. Kumar, S. Kumari, S.K. Dhawan, Recycling of plastic waste into tiles with reduced flammability and improved tensile strength, Process Safety and Environmental Protection 124(2019), 299-307.

[63] K.A. Wani, A.A. Dar, A. Gull, L. Ariana, Conversion of Waste into Different By-Products of Economic Value in India, Innovative Waste Management Technologies for Sustainable Development, $1^{\text {st }}$ Edition, IGI Global publishing, Hershey, Pennsylvania, 2019, 259-272.

[64] S. Pandey, M. Karakoti, S. Dhali, N. Karki, B. SanthiBhushan, C. Tewari, S. Rana, A. Srivastava, A.B. Melkani, N.G. Sahoo, Bulk synthesis of graphene nanosheets from plastic waste: An invincible method of solid waste management for better tomorrow, Waste management 88(2019), 48-55.

[65] A.R. Kamali, J. Yang, Q. Sun, Molten salt conversion of polyethylene terephthalate waste into graphene nanostructures with high surface area and ultra-high electrical conductivity, Applied Surface Science 476(2019), 539-551. 
[66] A. Rendón-Patiño, J. Niu, A. García, H. Doménech-Carbó, A. Primo, Polystyrene as Graphene Film and 3D Graphene Sponge Precursor, Nanomaterials 9(2019) 1, 101.

[67] A. Mukherjee, B. Debnath, S.K. Ghosh, Carbon Nanotubes as a Resourceful Product Derived from Waste Plastic-A Review, in: Waste Management and Resource Efficiency, ed. S. Ghosh, Springer, Singapore, 2019, 915-934.

[68] S.J. Kwon, H.K. Seo, S. Ahn, T.W. Lee, Value Added Recycling of Inexpensive Carbon Sources to Graphene and Carbon Nanotubes, Advanced Sustainable Systems 3(2019) 1, 1800016.

[69] R.A. Mir, O.P. Pandey, Waste plastic derived carbon supported $\mathrm{Mo}_{2} \mathrm{C}$ composite catalysts for hydrogen production and energy storage applications, Journal of Cleaner Production 218(2019), 644-655.

[70] T. Wei, Z. Zhang, Z. Zhu, X. Zhou, Y. Wang, Y. Wang, Q. Zhuang, Recycling of waste plastics and scalable preparation of $\mathrm{Si} / \mathrm{CNF} / \mathrm{C}$ composite as anode material for lithium-ion batteries, Ionics 25(2019) 4, 1523-1529.

[71] N.A. Elessawy, M. Elnouby, M. Gouda, M.S.M. Eldin, H.A. Farag, A.H. Konsowa, Simple Self-assembly Synthesis for Cost-Effective Alkaline Fuel Cell Bi-functional Electrocatalyst Synthesized from Polyethylene Terephthalate Waste Bottles, Journal of Electronic Materials 49(2020), 10091016.

[72] F.S. Hashem, T.A. Razek, H.A. Mashout, Rubber and plastic wastes as alternative refused fuel in cement industry, Construction and Building Materials 212(2019), 275-282.

[73] P.K. Saha, K.H. Karstensen, Coprocessing of Alternative Fuels and Resources in Indian Cement IndustryBaseline and Potential, in: Waste Valorisation and Recycling, ed. S. Ghosh, Springer, Singapore, 2019, 19 29.

[74] S. Sadala, S. Dutta, R. Raghava, T.S. Jyothsna, B. Chakradhar, S.K. Ghosh,
Resource recovery as alternative fuel and raw material from hazardous waste, Waste Management and Research 37(2019) 11, 1063-1076.

[75] N.D. Shiri, M.S. Krafft, W. Thurm, Plastic lumber product development using commingled waste plastics, AIP Conference Proceedings of Emerging trends in mechanical engineering 2018, ed. B.K. Gopalakrishna, S. Mudradi, Karnataka, India, August 10-11, 2018, AIP Publishing, Vol. 2080, Issue 1, 2019, 050007.

[76] K.R. Vanapalli, B. Samal, B.K. Dubey, J. Bhattacharya, Emissions and Environmental Burdens Associated with Plastic Solid Waste Management. Plastics to Energy: Fuel, Chemicals and Sustainability Implications, $1^{\text {st }}$ Edition, William Andrew Publishing, Norwich, New York, United States, 2019, 313342.

[77] S. Devasahayam, R.K.S. Raman, K. Chennakesavulu, S. Bhattacharya, Plastics-Villain or Hero? Polymers and Recycled Polymers in Mineral and Metallurgical Processing - A Review, Materials 12(2019), 655.

[78] R. Tuladhar, S. Yin, Production of recycled polypropylene (PP) fibers from industrial plastic waste through melt spinning process, in: Use of Recycled Plastics in Eco-efficient Concrete, ed. F. Pacheco-Torgal, J. Khatib, F. Colangelo, R. Tuladhar, Elsevier, 2019, 69-84. 